\title{
Tüketim Değerlerinin Satın Alma Niyeti ve Bağlılık Üzerindeki Rolü: Fırsat Sitelerine Yönelik Bir Araştırma
}

\author{
The Role of Consumption Values on Purchase Intention and Loyalty: an \\ Investigation on Daily Deal Sites
}

\section{Arş. Grv. Selen Öztürk - Arş. Grv. Selim Şerbetci - Şevket Necmettin Gürcan}

\begin{abstract}
Öz
Günümüzde yeni iletişim teknolojilerinin ve İnternet mecrasinin yaygin olarak kullanilmastyla birlikte tüketicilerin alş̧veriş yapma biçimleri önemli bir değişime uğramıştr. İnternetten alışveriş ve e-ticarete dair yeni iş modelleri, hem perakendeciler hem de tedarikçiler tarafindan olduğu kadar tüketicilerden de yüksek oranda talep görmektedir. Bu noktada tüketicilerin, İnternetten günlük indirimli alışveriş firsatları sunan firsat sitelerinden yapilan alışverişe atfettikleri değerin, boyutlar itibariyle, tüketici davranışları üzerindeki etkisinin incelenmesi çalışmanın amacını oluşturmaktadır. Tüketim değerlerinin, firsat sitelerinden satın alma niyeti ve firsat sitelerine duyulan bağhllk üzerindeki etki düzeylerini belirlemek amacıyla 316 kişi ile İnternet üzerinden anket çalışması gerçekleştirilmiştir. Çalışmanin sonuçları doğrultusunda tüketicilerin satı alma niyeti üzerinde tüketim değeri boyutları arasından en etkili olanın "duygusal değer" ve onu takiben "parasal fiyat", "itibar" ve "sosyal değer" boyutları olduğu ortaya çıkarken; firsat sitelerine duyulan bağhllk üzerinde ise en etkili boyutun "itibar" ve takiben "duygusal değer", "parasal fiyat" ve "sosyal değer" olduğu saptanmıştır.
\end{abstract}

Anahtar Kelimeler: Tüketim Değerleri, Firsat Siteleri, E-ticaret, Regresyon Analizi, Satın Alma Niyeti

\section{Abstract}

Today, with the intensive use of new communication technologies and the Internet, consumer shopping styles has changed considerably. Internet shopping and new business models on e-commerce is popular among not only by both retailers and suppliers, but also by consu-
}

mers themselves. At this point, the examination of effects of value dimensions that attributed to shopping from daily deal sites offering various discounts have on consumer behavior constitutes the purpose of the study. An Internet survey was conducted with 316 respondents to determine the level of effects of consumption values on purchase intention and consumer loyalty. According to the research results, the most influential value dimension on consumers' purchase intention was found to be "emotional value" that followed by "monetary price", "reputation" and "social value", whereas on consumer loyalty the most influential value dimension was found to be "reputation" that followed by "emotional value"," monetary price" and "social value" respectively.

Keywords: Consumption Values, Daily Deal Sites, E-commerce, Regression Analysis, Purchase Intention

\section{Giriş}

Günümüz dünyasında yeni teknolojilerin ve artan tüketici beklentilerinin, perakende sektöründe gerçekleşen değişimlerin pek çoğunu yönlendirdiği bilinmektedir. Tüketiciler, geçmişten bugüne, oldukça sabırsız, istedikleri şeyleri istedikleri zaman elde etmek isteyen ve istediklerini hemen ve uygun bir şekilde elde etmek için tüm firsatlardan yararlanan birey ya da topluluklar olarak tanımlanmıştır. Günümüzde ise tüketicilerin bu beklentilerinin en iyi şekilde karşılanmasını sağlayacak yeni teknolojiler ve çeşitli yeni teknolojik altyapıların olanak sağladığı yeni iş modelleri ve hizmetler mevcuttur. Bu yeni teknolojiler, tüketicilerin istediklerini hızlı bir șekilde bulmalarına,

Arş. Grv. Selen Öztürk, İstanbul Üniversitesi İşletme Fakültesi, selenoz@istanbul.edu.tr Arş. Grv. Selim Şerbetci, İstanbul Üniversitesi İşletme Fakültesi, ssserbetci@gmail.com Şevket Necmettin Gürcan, İstanbul Üniversitesi Sosyal Bilimler Enstitüsü Pazarlama ABD Doktora Öğrencisi, necmettingurcan@yahoo.com 
gerektiğinde daha detaylı bir şekilde araştırmaları ve diğer kişilerin söz konusu ürün ya da marka hakkında ne düşündüklerini öğrenmelerine; sonuç olarak kendileri için en uygun mal ve hizmetlere ulaşmaları ve bunları satın almalarına olanak tanır ya da yardımcı olur. Tüketiciler evde ya da işte iken, arabalarının içinde seyahat ederken ya da herhangi bir mağazada akıllı telefonlarını kullanırken bu gibi pek çok şeyi yapabilmektedir. Satın alma kararlarını verdiklerinde ise tüketiciler daha önce hiç olmadığı kadar bilgi sahibi olmaktadırlar (Dragt, 2012, s.3).

$\mathrm{Bu}$ durumu takiben, e-ticaret firmalarının müşterilerine sundukları değer önerileri ve bunları sunuç biçimleri sürekli bir değişim içerisindedir. İçerik açısından daha dolu olan İnternet siteleri ve sosyal ağların yaygınlaşması, e-ticarette yeni iş modellerini beraberinde getirmiştir. Bunlardan biri olan grup satın alma platformları ve/veya anlık olarak firsatlar sunabilen firsat siteleri, hem yerel hem küresel anlamda tüketicilere mal ve hizmetlerin yanı sıra kendine özgü müșteri deneyimi sunmaktadır (Hughes ve Beukes, 2012, s.921).

Potansiyel müşterilerine, firma websiteleri ile e-posta ve bireysel davetler yolu ile ulaşan firsat sitelerinin, bir açıdan sosyal medyanın büyümesi ile ortaya çıktığı söylenebilir. Groupon gibi İnternet tabanlı günlük firsat siteleri, son yıllarda hem tüketiciler hem de perakendeciler için popüler bir sosyal ticaret öğesi haline gelmiştir. Tüketiciler için sunulan büyük fiyat indirimleri, geleneksel alışverişe özgü zaman, ulaşım gibi maliyetlerden kurtulma fikri ve perakendeciler için ürüne yönelik tutundurma fırsatı düşünüldüğünde bu durum şaşırtıcı değildir. Tüketicileri cezbeden fiyat indirimleri, kampanyalara dair sürelerde ve yararlanabilecek kişi sayısındaki sınırlamalar ile fırsatlardan yararlanmak veya bunları paylaşmak amacıyla tüketicilerin oluşturdukları sosyal bağlantılar, bu sitelerin çalışma şeklini ve tutundurma stratejilerini özetler niteliktedir (Tuten ve Ashley, 2011, s.16-17).

Bu noktada, çalışmada ilk aşamada, tüketicilerin fırsat sitelerinden yapılan alışverişe atfettikleri değerin, boyutlar itibariyle ortaya çıkarılması amaçlanmıştır. $\mathrm{Bu}$ boyutlardan hangisi veya hangilerinin tüketicilerin satın alma niyetleri ve firsat sitelerine duydukları bağlılık üzerinde etkili ya da daha fazla etkili olduğunun açıklanması ile ise pazarlama literatürüne ve uygulamada bu sektörde hizmet vermekte olan firmalar ya da girişimcilere, e-ticaret ve fırsat sitelerinin işleyişi açısında katkı sağlayacağı düşünülmektedir.

\section{Araştırmanın Konusu}

Bu çalışmada, ülkemizde son zamanlarda oldukça popüler olan firsat sitelerinden yapılan alışverişe yönelik satın alma niyeti ve müşteri sadakatine tüketim değeri teorisi açısından yaklaşılması hedeflenmiştir. $\mathrm{Bu}$ İnternet sitelerinin sunmuş oldukları hizmetlerin, tüketicinin değer algılamalarını nasıl ve ne yönde etkilediklerinin ortaya konması çalışmanın konusunu oluşturmaktadır.

Çalışmanın bu bölümünde tüketim değerleri ve günlük fırsat siteleri başlıkları altında, çalışma konusu çerçevesinde tanım ve açılamalara yer verilmektedir. Öncelikli olarak günlük firsat sitelerine dair tanımlamalar ile küresel ve yerel açıdan sektörel işleyiş ve gelişmelerden bahsedilmiştir. Takiben tüketim değerleri üzerine teoriler özetlenmiş ve aynı zamanda bu çalışmaya dayanak oluşturan çeşitli çalışmalara yer verilmiştir.

\section{Günlük Fırsat Siteleri}

Günlük firsat (deal of the day) deyimi, İnternetten indirimli satış yapan ve tutundurma amaçlı olarak genellikle sosyal medyayı kullanan e-ticaret sitelerini tanımlamak için kullanılmaktadır. Groupon gibi fırsat siteleri öncelikli olarak e-posta listelerindeki müşterileri bu indirimlerden haberder ederler. Bu tip teklifleri alanlar ise hem kendileri bu indirimli satıştan yararlanmak hem de çevresini bu konudan haberdar etmek ve yönlendirmek konusunda teşvik edilmiş olmaktadır. Sosyal bağlantılara dayanan bu öğe, sadece bireysel satın alımları artırmakla kalmayıp, aynı zamanda gelecekte elde edilmesi planlanan firma gelirleri için firmanın ihtiyaç duyacağı müşteri veri tabanını genişletmesi sebebiyle oldukça önemlidir. Günlük firsat siteleri bu yönleriyle İnterneti kullanan yeni bir ticaret yapma biçimidir (Boon vd., 2012, s.137).

Hâlihazırda, fiyat beklentileri tüketiciler için önemli bir referans noktasıdır ve bu yüzden fiyata dair tutundurma çabaları, bir malı ya da hizmeti satın almak için tüketiciyi fazlasıyla teşvik edebilmektedir. (Raghubir, 1998). Frrsat siteleri; İnternet perakendeciliğinin geleneksele oranla sahip olduğu daha esnek ve daha düşük maliyetli olan yapısı ile, daha geniş bir ürün gamı içerebilmesi, hızlı işlem yapma olanağı ve tüketiciye daha fazla rahatlık ile kişiselleştirme imkânı sunabilen perakendecilik anlayışını (Srinivasan vd., 2002), fiyat temelli tutundurma ve sosyal öğesi ile bir adım daha ileri taşımaktadır. Bu özellikleriyle günlük firsat siteleri özellikle son yıllarda küresel çapta 
popüler olmuştur. Hızlı büyümeye, günlük fırsat siteleri endüstrisinden elde edilen gelirlerin, Amerika Birleşik Devletleri'nde yıllık \%100 ve üzerinde bir oran ile artmakta olduğuna dair analiz sonuçları örnek olarak gösterilebilir. Fırsat sitesi sahibi firmalar ve birçok pazarlama uzmanı, örneğin bu perakende anlayışının, küçük ve orta ölçekteki yerel işletmelere, üretmiş oldukları değerleri mevcut ve daha fazla sayıda potansiyel müşteri ile buluşturabilmesi sebebiyle önemli avantajlar sunduğu görüşündedir. Bu tip indirimleri takip eden yeni müşteri kitlesinin belirli bir kısmı söz konusu işletmenin uzun süreli olarak satışlarını ve karlılığını arttırabilir ve firmanın sadık müşterileri haline de gelebilirler. Ayrıca aynı işletmeden söz konusu ürünü indirimsiz fiyatı ile satın alma niyeti ya da imkânı olmayan, fiyat konusunda hassas tüketicileri cezbetmesi ve mobilitesi ile de önemli bir pazara hitap etmektedir (Gupta, 2012, s.5).

Yeni iletişim teknolojilerinin ve bu bağlamda İnternet mecrasının yaygın olarak kullanılmasıyla birlikte Türk tüketicisinin alışveriş yapma biçimleri de önemli bir değişime uğramıştır. Bu değişimin etkisiyle birlikte tüketiciler, küresel anlamda değişim içerisinde olan İnternet üzerinden alışveriş alışkanlıklarına kısa sürede uyum sağlamayı başarmışlardır (Pelenk vd., 2011). Türkiye, Çin haricinde dünyada en çok Groupon benzeri günlük firsat sitesi bulunan ülkedir. Çin'de bir istisna olarak 1000'den fazla Groupon benzeri faaliyet gösteren firma bulunmaktadır (Afra, 2011). Türkiye'de online alışveriş yapan kullanıcıların yaklaşık \%20'si özel davet sistemiyle üye olunan ve özel alışveriş kulübü olarak adlandırılan sitelerinden faydalanmaktadır. Alandaki yatırımların artmasıyla birlikte marka ürünlerin çok uygun fiyatlara satıld1$\breve{g} 1$ bu sitelere Türkiyede ilgi her geçen gün artmaktadir (Ekonomist, 2011, s.46-47). Bu sitelerin yanı sira daha özelleştirilmiş ürünlerin satışını gerçekleştiren yeni alışveriş siteleri de sektörde yer almaya başlamıştır. Örneğin, sadece ev eşyası satışı yapan evim.net, yalnızca ayakkabı satışı yapan zizigo.com gibi özel alışveriş siteleri bulunmaktadır (Pelenk vd., 2011).

Son yıllarda popüler medyada ve perakende sektöründe gözde olmasına karşın firsat sitelerine yönelik, sağladıkları ekonomik ve diğer faydaların yanında, bu tüketim modelinin tüketici bakış açısından nerede konumlandığına dair yapılması gereken çalışmaların sayıca eksik olduğu görülmektedir. Genel olarak bu fırsat sunumlarının nasıl işe yaradığı/yaramadığı ve tüketiciler için potansiyel değeri gibi hususlar, araşt1- rrlması gereken çeşitli alanları temsil etmektedir. Örneğin sektör açısından bir firmanın, çeşitli nedenlerle yerine getirilmemiş bir firsat teklifinin, doğrudan ve dolaylı olarak kendisi üzerindeki etkilerine dair detaylı bilgiye sahip olması gerekmektedir. (Gupta, 2012, s.6)

\section{Tüketim Değerleri}

Değer, tüketici tutumları ve davranışlarını şekillendiren önemli güçlerden birisidir. Tüketim değeri, herhangi bir alışveriş esnasında ya da sonrasında, bireye ait tutum ve bireyin sergilediği davranışlarla ilişkili bir kavram olarak pazarlama literatüründe yer almıştır. Zeithaml'a (1988, s.14) göre algılanan değer nitel ya da nicel, subjektif ya da objektif tüm faktörler dikkate alınarak tüketicinin almayı umduğu ile verdiğinin karşıllı̆ında elde ettiği faydadır. Kashyap ve Bojanice (2000, s.46) göre ise değer, tüketicinin verdiği (fiyat, fedakarlık) ve karşılığında aldığından (fayda, kalite ve yararlar) daha fazlasıdır. Satın alma karar sürecinde tüketiciler herhangi bir mal ya da hizmetin niteliklerini değerlendirme yolu ile elde edecekleri faydayı sorgulayabilmektedir. Bunun yanı sıra tüketicinin ödedikleri bedel, hem parasal hem de parasal olmayan şeylerden (ilgili mal/hizmete ulaşım kolaylığı, ulaşmakta katlanılan maliyetler) oluşmaktadır. Bu yöndeki tüketici araştırmaları literatürünü de dikkate alarak, tüketim değerinin sadece ekonomik faydalara (kalite-fiyat değerlemeleri vs.) odaklanmadığı söylenebilir.

"Bir mal ya da hizmetin niteliklerine yönelik tüketicinin atfettiği önem" olarak tanımlanabilen tüketim değeri kavramı, mal ve hizmetlere yönelik talep oluşturulmasına katkısı ve söz konusu mal veya hizmetin kabul edilebilirliği ya da satın alınmasına gerekçe olabilmesi sebebiyle incelenen bir konu olmuştur (Xiao ve Kim, 2009, s.612). Pazarlama literatüründe, tüketim değeri kavramını anlamaya yönelik sayısız çalışma mevcuttur (Sheth vd., 1991a, 1991b; Dodds vd., 1991; Babin vd., 1994; Woodruff, 1997; Petrick, 2002; Chen ve Dubinsky, 2003; Lee vd., 2004; Kleijnen vd., 2007; Chi vd., 2008; Bodker vd., 2009; Xiao ve Kim, 2009; Boksberger ve Melsen, 2011; Kim vd., 2011).

Tüketicinin değer algılaması, çeşitli bileşenlerden meydana gelmektedir. Değer kavramı, kendi içerisinde farklı yapılara sahip çeşitli alt bileşenler ya da boyutlardan oluşan geniş bir kavram olarak düşünülmelidir (Sweeney ve Soutar, 2001; Smith ve Colgate, 2007; Cheng vd., 2009, s.145). Tüketicilerin, bir ürünü satın alması ya da almaması, iki ürün ya da 
marka arasından hangisini satın alacağı konusunda verdikleri kararları incelemek amaciyla Sheth ve diğerleri (1991a) bu şekilde çok boyutlu bir model oluşturmuştur (Boksberger ve Melsen, 2011, s.232). Sheth ve diğerleri (1991a, 1991b) tüketicilerin, farklı ürün gruplarına farklı değerler atfettiklerini ve bu durumun, geri dönüşünde satın almaya yönelik motivasyonları etkileyeceğini öne sürmüştür. Örneğin, otomobil bir tüketici tarafından tarzı (sosyal değer) için satın alınmış olabiliyorken, bir başka tüketici tarafından fonksiyonel değerine göre (yakıt ekonomikliği) tercih edilmiş olabilmektedir. Yaptıkları çalışmada tüketicinin satın alma tercihini açılayan değerler beş boyutla açıklanmıştır. Buna göre fonksiyonel değer, karar alma durumundaki tüketicinin fayda alg1lamasından kaynaklanmaktadır. Sosyal değer, sosyal gruplar ve kabul görme ile ilgili ürüne atfedilen değerdir. Duygusal değer, ürüne yönelik duygusal tepkilerle ilgilidir, o ürünün kişide oluşturduğu haz ve zevk duygularını ifade eder. Yenilik değeri, ürünlerin tüketicilerin yaşamına getirdiği yenilik, uyandırdıkları merak ve bilgi edinme arzularını tetiklemesi ile ilgilidir. Durumsal değer ise tüketicilerin alternatifler arasından seçimini karşılaştı̆̆ belirli durumlara göre yapabilmesi ile açıklanmaktadır.

Sheth ve diğerlerinin (1991a, 1991b) bu bakış açısıyla geliştirmiş olduğu tüketim değeri sınıflaması, çeşitli durum senaryolarını geniş kapsamda ele alması sebebiyle pek çok araştırma için dayanak noktası olmuştur (Pope, 1998; Lapierre, 2000; Long ve Schiffman, 2000; Sweeney ve Soutar, 2001; Petrick, 2002; Wang vd., 2004; Xiao ve Kim, 2009). Sweeney ve Soutar (2001), perakendecilik alanında çeşitli giyim ve ev eşyaları gibi ürün grupları itibariyle gerçekleştirdikleri çalışmada, tüketim değerlerini üzerine bir ölçek geliştirmiş ve bunu istatistiksel açıdan test etmiştir. Sonuç olarak, çalışmada tüketim değerleri; fonksiyonel değer, sosyal değer, duygusal değer ve parasal değer olmak üzere dört boyutta açıklanmıştır. Buna göre, tüketiciler ürünleri sadece fonksiyonel olarak üründen beklenen performans, paraya karşılık değer vb. ile değil; aynı zamanda üründen alınan haz (duygusal değer) ve ürünün, bireyin sosyal çevresi için ifade ettikleri (sosyal değer) ile değerlendirmektedir. Geliştirilmiş olan ölçeğin, tüketiciler açısından, hem satın alım öncesi hem de satın alım sonrasındaki aşamalar için güvenilir ve geçerli olduğu tespit edilmiştir (Sweeney ve Soutar; 2001, s. 216).

Petrick (2002, s.125) ise hizmet sektörü üzerine gerçekleştirdiği çalışma sonucu beş boyuttan oluşan bir tüketim değeri modeli elde etmiştir. Bu boyutlar; kalite (fonksiyonel değer), duygusal değer, parasal fiyat, davranışsal fiyat ve itibardır. Bu ölçekte yer alan duygusal değer boyutu, üründen alınan haz duygusuna dair kişisel fikir ve yargıları içermektedir. Parasal fiyat, bir hizmete biçilmiş olan fiyata dair tüketici alg1sinı ifade ederken; davranısssal fiyat, bu hizmeti alırken katlanılan fiyat dışı faktörleri (harcanan zaman, çaba vb.) kapsamaktadır. İtibar boyutu ise hizmet sunan kişi ya da firmanın imajı temel alınarak, söz konusu hizmetin prestiji ya da statüsüne dair tüketicinin algisını ifade eder.

Tüketim değerleri için, bu çalışma kapsamında Sweeney ve Soutar (2001) ve Petrick (2002)'in geliştirdiği model ve ölçekler temel alınmaktadır. Çalışma kapsamında tüketim değerleri söz konusu bakış açısı doğrultusunda çok boyutlu bir kavram olarak ele alınmış ve incelenmiştir.

\section{Araştırmanın Amacı}

Değer, pazarlama ve e-ticaret açısından tüketici davranışlarını (nihai satın alma kararına etkisi ile) öngörmek amacıyla araştırılan önemli bir kavram olmuştur (Zeithaml, 1988; Dodds vd., 1991; Sheth vd., 1991a; Babin vd., 1994; Kim vd., 2007; Kim vd., 2011, s.229). Kalite ve müşteri memnuniyeti gibi faktörler ile birlikte yüksek değer algısının, çeşitli bireysel, çevresel ya da ürüne dayalı faktörlere bağlı olarak değişebilmekle birlikte, tüketicinin satın alma niyeti ve bağlılığ 1 üzerinde olumlu etkisi olduğuna dair genel bir kanı mevcuttur (Petrick, 2004; Boksberger ve Melsen, 2011, s.233). Güncel bir işletme modeli olarak firsat siteleri ve bu sitelerden yapılan alışverişe dair tüketici tutum ve davranışlarının da bu çerçevede ele alınmasının gerekli olduğu düşünülmektedir. Bu doğrultuda, tüketim değerlerinin tüketici davranışlarına olan etkileri açısından incelenmesi bu araştırmanın çıkış noktası olmuştur. Araştırmanın temel amacı, fırsat sitelerinden (grupon, markafoni, sehirfırsatları vb.) alışveriş yapanların satın alma niyetlerinin ve firsat sitelerine olan bağlılık durumunun, farkl tüketim değeri boyutlarına göre nasıl ve ne düzeyde etkilendiğinin belirlenmesidir. Araştırmada öncelikli olarak tüketim değerlerine ilişkin boyutların belirlenmesi, sonrasında satın alma niyeti ve firsat sitelerine duyulan bağll1ık üzerinde üzerinde bu farklı değer boyutlarının etkisinin nasıl farklılaştı̆̆ının ortaya koyulması hedeflenmiştir. 
Çalışmanın amaçları doğrultusunda edinilen bulguların değerlendirilmesi ve yorumlanması ile uygulamada, bu alanda konumlandırma, iletişim ve mesaj stratejileri geliştirirken dikkat edilecek hususlar açısından pazarlama yöneticileri ya da girişimcilere yol gösterici olacağı düşünülmektedir. Ayrıca tüketim değerleri itibariyle hangi boyutların öne çıtığının bilinmesi, stratejik ve operasyonel anlamda etkin hizmet sunmaları için bu alanda hizmet veren işletmelere katkı sağlayacaktır. Örneğin, İnternet sitesi tasar1$\mathrm{m}$, firmanın müşteri ile iletişimi, mal ve hizmetlere dair kampanya düzenlemeleri ya da genel anlamda faaliyetlerin yürütülmesi için gerekli kaynakların tahsisi ve kullanımı gibi hususlarda firmalar için en fazla önem arz eden noktalara işaret etmesi sebebiyle çalışmanın faydalı olacağı öngörülmektedir.

\section{Araştırmanın Değişkenleri}

Araştırmada tüketim değerleri, satın alma niyeti ve fırsat sitelerine duyulan bağlılığı ölçmeye ilişkin değişkenler olmak üzere üç değişken grubu yer almaktadır. Araştırma modelinde tüketicilerin farklı tüketim değeri boyutlarına göre firsat sitelerinden satın alma niyetleri ve fırsat sitelerine yönelik duydukları bağlılık derecelerinin farklılık göstereceği düşünülmektedir. Araştırma amacı doğrultusunda bu çalışmada tüketim değerleri 34 değişken ile ölçülmüştür. Satın alma niyetini ölçmeye yönelik dört, firsat sitelerine bağlllık üzerine yedi; cinsiyet, yaş, medeni durum, gelir, eğitim ve meslek olmak üzere sosyo-demografik özellikleri ölçmeye yönelik ise çoktan-seçmeli olarak ifade edilen altı değişken mevcuttur.

\section{Araştırmada yer alan değişkenler:}

a) Tüketim değerlerini ölçmeye yönelik değişkenler (Beşli likert tipi ölçek ile oluşturulmuş yargılar)

Toplam 34 ifadeden oluşan bu ölçek, çeşitli mal ve hizmet grupları için tüketicilerin değer algılamalarını ölçmeyi amaçlayan araştırmacıların (Sweeney ve Soutar, 2001; Petrick, 2002) geliştirdiği ölçekler temel alınarak oluşturulmuştur. Bunun yanı sıra Türk tüketicisi üzerinde yapılan çalışmalar (Sarıyer, 2008; Turan ve Çolakoğlu, 2009) ve bu araştırma dâhilinde yapılan ön anket çalışması da dikkate alınarak ölçeğe son hali verilmiştir. Araştırma ile ilgili saha çalışmasına geçilmeden önce gerçekleştirilen ön çalışma kapsamında oluşturulan taslak anket formu 45 kişilik bir gruba uygulanmış, ölçekler üzerinde dil ve anlatım bakımından gerekli düzeltme ve sadeleştirmeler gerçekleştirilmiştir. Ayrıca, tüketim değerleri ve diğer tüketici özelliklerini ölçmede kullanılan ifadelerin dilimize doğru şekilde uyarlanmasına dikkat edilmiştir.

\section{b) Satın alma niyetini ölçmeye yönelik değişkenler} (Beşli likert tipi ölçek ile oluşturulmuş yargılar)

Mal ya da hizmetler üzerine tüketicinin değer alg1laması, satın alma niyeti ve satın alma davranışının belirleyici faktörlerindendir (Zeithaml, 1988; Sheth vd., 1991b; Kashyap ve Bojanic, 2000; Zeithaml ve Bitner, 2000; Srisutto, 2010). Çalışmada yer alan bu dört değişken (En kısa zamanda satın alacağım mal/ hizmeti firsat sitelerinden alma olasıllğım yüksektir/ Firsat sitelerinden en kısa zamanda mal/hizmet satın alma isteğim fazladır/ Gelecekte firsat sitelerinden alı̧veriş yapmaya devam edeceğim/ İnternet üzerinden bir sonraki alışverişimi firsat sitelerinden yapmak isterim), Dodds ve diğerlerinin (1991) çalışması temel alınarak Devaraj ve diğerleri (2002) ve Kim ve diğerlerinin (2009) araştırmalarında kullandıkları değişkenler doğrultusunda tercih edilmiş ve uyarlanmıştır.

\section{c) Fırsat sitelerine yönelik bağlılığı ölçen değişken-} ler (Beşli likert tipi ölçek ile oluşturulmuş yargılar)

Fırsat sitelerine yönelik bağlllı̆̆ ölçen değişkenlerin (Satın alacağım bir mal/hizmeti firsat sitelerinden almak isterim/ Her zaman firsat sitelerinden alışveriş yapmayı tercih ederim/ Firsat sitelerinden alışveriş yapmayı arkadaşlarıma da tavsiye ederim/ Çevremdekileri firsat sitelerini kullanmaları konusunda cesaretlendiririm/ Son zamanlarda satın aldığım mal/ hizmetlerin çoğunu fırsat sitelerinden aldım/ Fırsat siteleri hakkındaki deneyimlerimi İnternet üzerinden paylaşırım/ Fırsat sitelerini kullanmalarını arkadaşlarıma İnternet üzerinden tavsiye ederim) oluşturulmasinda, Flavián ve Guinalíu (2007), Manzur ve diğerleri (2011) ve Wu (2011)'nun çalışmalarından yararlanılmıştır.

\section{Araştırmanın Hipotezleri}

Literatürde tüketim değerlerinin, tüketicilerin satın alma niyeti ve bağlılığı üzerindeki etkisine yönelik genel olarak İnternetten alışveriş üzerine yapılmış olan ve daha önce de belirtilen çeşitli çalışmalar mevcut iken, fırsat siteleri açısından bu bağlamda sınırlı sayıda çalışma bulunmaktadır. Özellikle tüketim değerleri çerçevesinde, değer ile tüketici tatmini, satın alma niyeti ve ağızdan ağıza iletişimin etkileşimine 
dair Tuten ve Ashley (2011) tarafından yapılmış olan çalışma, İnternet perakendeciliğindeki bu iş modeline yönelik tüketici tutum ve davranışlarını değer algısı kavramı ile ilişkilendirmiştir.

$\mathrm{Bu}$ araştırma kapsamında tüketim değerleri; fonksiyonel değer, duygusal değer, sosyal değer, parasal fiyat, davranışsal fiyat ve itibar olarak altı boyutta ele alınmıştır. Fonksiyonel değer, alınan hizmetin tüketici açısından algılanan fonksiyonel faydalarına ve kalitesine işaret ederken; duygusal değer, alışverişten alınan keyif ve heyecan duygusunu, sosyal değer ise bireyin ürün/alışveriş tercihine dair çevresi ile bağlantıları ve etkileşimini ifade etmektedir (Sweeney ve Soutar, 2001; Petrick, 2002, s.125; Srisutto, 2010, s.2627). Parasal fiyat, ürün fiyatlandırmasına dair tüketici algısını ifade ederken; davranışsal fiyat, bu hizmeti alırken tüketicinin katlandığı fiyat dışı faktörleri (harcanan zaman, çaba vb.) kapsamaktadır (Petrick, 2002, s.125, Boksberger ve Melsen, 2011, s.231). İtibar ise hizmet sunan kişi ya da firmanın imajı temel alınarak, söz konusu hizmetin prestiji ya da statüsüne dair tüketicinin algisını ifade eder. (Petrick, 2002, s.125). Literatürde yer alan diğer çalışmalar da (Sheth vd., 1991a; Boksberger ve Melsen, 2011; Kim vd., 2011; Tuten ve Ashley, 2011; Ar, 2012) dikkate alınarak, bu boyutların tüketicilerin satın alma niyeti üzerinde pozitif etkisi olduğuna dair araştırmanın amacı doğrultusunda geliştirilen hipotezler şu şekildedir:

$\mathrm{H}_{1}$ : Tüketim değerleri ile tüketicilerin fırsat sitelerinden satın alma niyeti arasında pozitif yönlü bir ilişki vardir.

$\mathrm{H}_{1 \mathrm{a}}$ : Fonksiyonel değer algısı satın alma niyeti üzerinde pozitif yönlü etki yapar.

$\mathrm{H}_{1 \mathrm{~b}}$ : Duygusal değer algısı satın alma niyeti üzerinde pozitif yönlü etki yapar.

$\mathrm{H}_{1 c}$ : Sosyal değer algısı satın alma niyeti üzerinde pozitif yönlü etki yapar.

$\mathrm{H}_{1 \mathrm{~d}}$ : Parasal fiyat algısı satın alma niyeti üzerinde pozitif yönlü etki yapar.

$\mathrm{H}_{1 \mathrm{e}}$ : Davranışsal fiyat algısı satın alma niyeti üzerinde pozitif yönlü etki yapar.

$\mathrm{H}_{1 \mathrm{f}}$ : İtibar satın alma niyeti üzerinde pozitif yönlü etki yapar.

Bağll1ık, tüketicinin bir firmanın müşterisi olmaya devam etmeye yönelik taahhütünü ve çabasını içerir. Ayrıca söz konusu ürün ya da markayı satın almaya ve ağızdan ağıza iletişim davranışına yönelik istekliliğini ifade eden bir yönü bulunmaktadır (Pihlström, 2008, s.27). Değer kavramı ve tüketici bağlllı̆̆ ilişkiyi araştırmaya yönelik yapılmış çeşitli çalışmalar (Sirdeshmukh vd., 2002; Johnson vd., 2006; Philström, 2008) literatürde mevcuttur. Tüketim değerlerinin, tüketicilerin bağlllığı üzerinde pozitif etkisi olduğuna yönelik yapılmış olan çeşitli çalışmalar da (Luarn ve Lin, 2003; Wang vd., 2004; Chang vd., 2009; Boksberger ve Melsen, 2011; Tuten ve Ashley, 2011) dikkate alarak bu boyutlara dair geliştirilen hipotezler ise aşağıda yer almaktadır:

$\mathrm{H}_{2}$ : Tüketim değerleri ile tüketicilerin firsat sitelerine duydukları bağlılık arasında pozitif yönlü bir ilişki vardir.

\footnotetext{
$\mathrm{H}_{2 \mathrm{a}}$ : Fonksiyonel değer algısı fırsat sitelerine duyulan bağlılık üzerinde pozitif yönlü etki yapar.

$\mathrm{H}_{2 \mathrm{~b}}$ : Duygusal değer algısı fırsat sitelerine duyulan bağl1lık üzerinde pozitif yönlü etki yapar.

$\mathrm{H}_{2 \mathrm{c}}$ : Sosyal değer algısı firsat sitelerine duyulan bağlılık üzerinde pozitif yönlü etki yapar.

$\mathrm{H}_{2 \mathrm{~d}}$ : Parasal fiyat algısı firsat sitelerine duyulan bağlılık üzerinde pozitif yönlü etki yapar.

$\mathrm{H}_{2 \mathrm{e}}$ : Davranışsal fiyat algısı firsat sitelerine duyulan bağlılık üzerinde pozitif yönlü etki yapar.

$\mathrm{H}_{2 \mathrm{f}}$ : İtibar firsat sitelerine duyulan bağlilık üzerinde pozitif yönlü etki yapar.
}

\section{Örnekleme Süreci}

Araştırmanın anakütlesini, fırsat sitelerinden haberdar, firsat sitelerinde hâlihazırda aktif üyeliği bulunan ve bu sitelerden alışveriş yapmış olan 18 yaşından büyük tüketiciler oluşturmaktadır. Araştırmanın örnek büyüklüğü e=0,05 ve $\alpha=0,05$ düzeyine göre hesaplanmıştır. Anakütle standart sapma ve varyanslarının bilinmesi çoğu kez olanaksız olduğu için bunların tahmin edilmesi gerekir. Böyle bir tahmini oranlar üzerinden yapmak çok kolaydır. Çünkü bu oranlar hiçbir bilgi olmasa dahi p(1-p)'nin en yüksek olduğu 0,5x0,5 değeri esas alınabilir. Tüm bu nedenlerden uygulamada en yaygın kullanılan örnekleme formülü (Kurtuluş, 2010, s.67), n=p(1-p) / (e/z)2 dir. Buna göre örnek büyüklüğü 385 olarak belirlenmiştir.

Araştırmada, veri ve bilgi toplama yöntemi olarak "İnternet üzerinden anket" yöntemi kullanılmıştır. Araştırma ile ilgili saha çalışmasına geçmeden önce anket formunu oluşturacak ölçeklere nihai halinin verilmesinde ikincil kaynakların yanı sıra, ön çalışma 
sonucu elde edilen tüketici tepkilerinden yararlanılmıștır. Araștırmada, ön çalıșma kapsamında olușturulan taslak anket formu 45 kişilik bir gruba uygulanmıș, ölçekler üzerinde dil ve anlatım bakımından gerekli düzeltme ve sadeleștirmeler gerçekleştirilmiștir. Tüketim değerleri ve tüketici özelliklerini ölçmede kullanılan ifadelerin dilimize doğru ve anlaşılır şekilde uyarlanmasına dikkat edilmiştir. Araştırma 1-20 Haziran 2012 tarihleri arasında gerçekleştirilmiştir. Fursat sitelerinde aktif üyeliği bulunan ve son altı ay içerisinde mal/hizmet satın alımı gerçekleştirmiş tüketiciler kolayda örnekleme yöntemi ile örnek kapsamına dâhil edilmiştir. Hâlihazırda anakütleye dair ve bunun yanı sıra seçilecek örnek bireyler hususunda alışverişini son altı ayda gerçekleştirmiş olan tüketicilere ait herhangi bir veri olmaması nedeniyle, araştırma kapsamında anket linki cevaplayıcılara İnternet üzerinden çeşitli yollarla gönderilmiştir. Bu aşamada, çeşitli bloglar, forumlar, genel olarak İnternetten alış- verişe yönelik oluşturulan sanal mecralar ve sosyal gruplar ile çeşitli mail grupları vasıtasıyla anketin daha fazla sayıda aktif kullanıcıya ulaştırılmasına dikkat edilmiștir ve toplamda 1099 kișiye ulașılmıștır. Bu cevaplayıcılardan 399'u son altı ay içerisinden firsat sitelerinden herhangi bir satın alım gerçekleştirmemeleri sebebiyle araştırma kapsamına dâhil edilmemiştir. Ulaşılan 384 kişi ise anketi tamamlamadan İnternet sayfasından ayrıldığı için cevapları geçerli sayılmamıştır. Toplamda çalışma kapsamına dâhil edilen anket sayısı ise 316 olmuştur. Bu durumda \%5 olarak hesaplanmış olan tolerans düzeyinin yeni örnek büyüklügüne göre $\% 5,51$ olduğu tespit edilmiştir.

\section{Araştırma Sonuçları}

Çalışma kapsamında değerlendirmeye alınan katılımcıların sosyo-demografik özelliklerine dair özet bilgiler aşağıda Tablo 1'de yer almaktadır.

Tablo 1. Cevaplayıcıların Sosyo-demografik Özellikleri ( $n=316)$

\begin{tabular}{|c|c|c|c|c|c|c|c|}
\hline & & Sayt & $\%$ & & & Sayt & $\%$ \\
\hline \multirow{2}{*}{ 莺 } & Kadın & 156 & 49,4 & \multirow{2}{*}{ 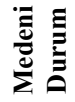 } & Evli & 112 & 35,4 \\
\hline & Erkek & 160 & 50,6 & & Bekâr & 204 & 64,6 \\
\hline \multirow{5}{*}{$\stackrel{\infty}{\pi}$} & 24 ve alt1 & 65 & 20,6 & \multirow{7}{*}{ 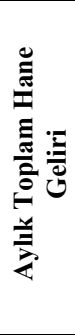 } & 1000 TL ve altı & 26 & $8,8,2$ \\
\hline & $25-34$ & 198 & 62,7 & & $1001-2000 \mathrm{TL}$ & 80 & 25,3 \\
\hline & $35-44$ & 38 & 12,0 & & 2001-3000 TL & 74 & 23,4 \\
\hline & $45-54$ & 12 & 3,8 & & $3001-4000 \mathrm{TL}$ & 42 & 13,3 \\
\hline & 55 ve üzeri & 3 & 0,9 & & $4001-5000 \mathrm{TL}$ & 26 & 8,2 \\
\hline \multirow{8}{*}{$\frac{\frac{u}{\underline{e}}}{\frac{g}{g}}$} & Özel Sektör Çalışanı & 162 & 51,3 & & $5001-6000 \mathrm{TL}$ & 24 & 7,6 \\
\hline & Kamu Sektörü /Memur & 49 & 15,5 & & 6001 TL ve üzeri & 44 & 13,9 \\
\hline & Serbest Meslek / Esnaf & 20 & 6,3 & \multirow{6}{*}{ 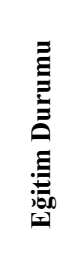 } & & & \\
\hline & Emekli & 3 & 0,9 & & İlkokul/Ortaokul & 2 & 0,6 \\
\hline & Ev Hanımı & 4 & 1,3 & & Lise & 35 & 11,1 \\
\hline & Öğrenci & 46 & 14,6 & & Üniversite & 175 & 55,4 \\
\hline & Çalışmıyorum & 12 & 3,8 & & YL /Doktora & 104 & 32,9 \\
\hline & Diğger & 20 & 6,3 & & & & \\
\hline
\end{tabular}

Cevaplayıcıların sosyo-demografik özelliklerine bakıldığında, \%49,4'ünün kadın, \%50,6'sının erkeklerden oluştuğu ve dengeli bir dağılım olduğu görülmektedir. Cevaplayıcıların yaş dağılımına baktığımızda, $\% 20,6$ 'sının 24 ve altı yaş grubunda bulunduğu görülmektedir. 25-34 yaș aralığında 198 kişi $(\% 62,7)$ bulunurken, 35-44 yaş aralığında 38 kişi (\%12) bulun- maktadır. Katılımcıların \%35,4'ü evliyken, \%64,6’s1 bekârdır. Katılımcıların \%51,3'üü özel sektör çalışanı iken, \%15,5’i kamu sektöründedir. Aylık hane geliri sorusuna cevaplayıcıların \%25,3'ü 1001-2000 TL aralığında cevabını verirken, \%23,4’ü 2001-3000 TL cevabını vermiştir. Katılımcıların eğitim durumu, $\% 55,4$ üniversite mezunu, \%32,9'u yüksek lisans/ 
doktora ve \%11'i lise mezunu olarak tespit edilmiştir. Tablo 2'de ise cevaplayıcıların son 6 ay içerisinde bu sitelerden kaç kez alışveriş yaptığ 1 ve toplam alışveriş tutarları yer almaktadır. 1-2 kez alışveriş yapanlar toplam cevaplayıcı sayısının \%36,7'sini, 3-4 kez alışveriş yapanlar ise \%30,7'sini oluşturmuştur. Cevaplayıcıların 67'si toplamda 0-100 TL tutarında alıveriş yaparken, 74’ü 101-200 TL tutarları arasında alışveriş yaptığını belirtmiştir. Alışveriş tutarı 201-300 TL aralığında olan 59 kişi mevcut iken, 301-400 TL aralığında 38 kişi yer almıştır. Öne çıkan noktalardan biri de yapılan toplam alışveriş tutarı arttıkça alışveriş yapmış olan cevaplayıcıların sayısının azalmasıdır.

Tablo 2. Cevaplayıcıların Fırsat Sitelerinden Satın Alma Alışkanlıkları

\begin{tabular}{l|c|c|l|c|c}
\hline $\begin{array}{c}\text { Son } 6 \text { ay içerisinde firsat sitelerinden kaç kez } \\
\text { alıșveriş yaptınız? }\end{array}$ & \multicolumn{2}{c}{$\begin{array}{c}\text { Son } 6 \text { ay içerisinde firsat sitelerinden yaptığınız } \\
\text { alșverişlerinizde toplam ne kadar para harcadınız? }\end{array}$} \\
\hline \hline & Sayı & $\%$ & & Sayı & $\%$ \\
\hline \hline $1-2 \mathrm{Kez}$ & 116 & 36,7 & $0-100 \mathrm{TL}$ & 67 & 21,2 \\
\hline $3-4 \mathrm{kez}$ & 97 & 30,7 & $101-200 \mathrm{TL}$ & 74 & 23,4 \\
\hline $5-6 \mathrm{kez}$ & 37 & 11,7 & $201-300 \mathrm{TL}$ & 59 & 18,7 \\
\hline $7 \mathrm{kez} \mathrm{ve} \mathrm{üzeri}$ & 66 & 20,9 & $301-400 \mathrm{TL}$ & 38 & 12,0 \\
\hline Toplam & 316 & & $401-500 \mathrm{TL}$ & 25 & 7,9 \\
\hline & & & $501-600 \mathrm{TL}$ & 21 & 6,6 \\
\hline & & & $601-700 \mathrm{TL}$ & 6 & 1,9 \\
\hline & & & $701 \mathrm{TL}$ ve üzeri & 26 & 8,2 \\
\hline & & & Toplam & 316 & \\
\hline
\end{tabular}

Araştırma sürecinde elde edilen veriler ile öncelikli olarak ölçme aracının geçerlilik ve güvenilirlik analizi gerçekleştirilmiştir. Tüketim değerleri ölçeğine keşfedici faktör analizi uygulanmıştır. Sonrasında fırsat sitelerine duyulan bağlılık ve satın alma niyetine etki eden faktörlerin ağırlıkları doğrusal regresyon analizi ile belirlenmeye çalışılmıștır. Çalışmada tüketicilerin değer algılamaları 34 değişkenle ölçülmüştür. Hair ve diğerlerine (2010, s.118) göre faktör analizi sonucu faktörler tarafindan açıklanan toplam varyansın genellikle $\% 60$ ve üzerinde olması beklenir. Bunun yanı sira elde edilen faktör matrisinde, faktörlerde yer alan her bir değişkene ait faktör yükleri incelenmelidir. Faktör yükleri en az \%30 ile \%40 arasında yer almalıdır. \%50 ve üzerindeki faktör yükleri uygulamada anlamlı olarak kabul edilmektedir. \%70'in üzerindeki değerler ise faktörlerin yapısal olarak ölçeği iyi şekilde temsil ettiğini göstermekle birlikte herhangi bir analiz sonucu hedeflenen değerlerdir. Keşfedici fak- tör analizi sonucu faktör yükü 0,40 'nin altında olan değişkenler analiz dışında bırakılmış ve dolayısıyla faktör analizi 28 değişken üzerinden gerçekleştirilmiştir. Buna göre Tablo 3'de görüldügüü üzere 28 değişkenden oluşan tüketim değerleri ölçeğinin KMO değeri 0,868 olarak bulunmuştur. Bu değer KMO değerinin alt sınırı olan 0,50 'den oldukça yüksektir. Bunun yanı sıra değişkenlere ait korelasyon matrisinde ilgili tüm korelasyonların anlamlılı̆̆ını ölçen Bartlett testi sonucu da anlamlı çıkmış ve faktör analizinin bu ölçeğe uygulanabileceğini göstermiştir (Hair vd., 2010, s.105; Malhotra, 2010, s.638). Araştırmada yer alan tüketim değerleri ölçeğinde, faktörlerin gruplandırılmasında Temel Bileşenler Analizi ve Varimax Rotasyonu kullanılmıştır. Varimax rotasyonu, varyansın bütün faktörlerde en yüksek olmasını sağlamaktadır. Tüketicilerin değer algılamalarını ölçmeye yönelik ifadelere uygulanan faktör analizi sonucu toplam açılanan varyans $\% 68,4$ olmuştur. 
Tablo 3. Tüketim Değerleri Ölçeğine Uygulanan Faktör Analizi Sonucu

\begin{tabular}{|c|c|c|c|c|c|c|}
\hline \multicolumn{7}{|l|}{ Faktörler } \\
\hline & 1 & 2 & 3 & 4 & 5 & 6 \\
\hline \multicolumn{7}{|l|}{ Duygusal değer (Açıklanan varyans:\%14,579, Cronbach Alfa: } \\
\hline Fırsat sitelerinde alıșveriș yaparken kendimi iyi hissederim. & 834 & & & & & \\
\hline Fursat sitelerinde alısveris yaparken rahat hissederim. & 830 & & & & & \\
\hline Fırsat sitelerinde alışveriş yapmaktan zevk alırım. & ,790 & & & & & \\
\hline Kendimi iyi hissetmek amacıyla firsat sitelerinden alışveriş yaparım. &, 776 & & & & & \\
\hline Fırsat sitelerinde alıșveriș yapmak keyiflidir. &, 730 & & & & & \\
\hline Fırsat sitelerinde alışveriș yapmak zevkli değildir.* &, 588 & & & & & \\
\hline \multicolumn{7}{|l|}{ Parasal fiyat (Açılanan varyans:\%12,641, Cronbach Alfa: ,838) } \\
\hline Fırsat sitelerinde ödediğim paranın karşıllı̆̆ını aldığıma inanıyorum. & &, 813 & & & & \\
\hline Fırsat siteleri ödediğim paraya karş1lık iyi bir değer sunarlar. & & ,797 & & & & \\
\hline $\begin{array}{l}\text { Firsat sitelerinde diğer mağazalara göre } \mathrm{mal} / \text { hizmetler uygun fiyatlarla } \\
\text { sunulur. }\end{array}$ & &, 723 & & & & \\
\hline $\begin{array}{l}\text { Fırsat sitelerinden alışveriş yapmamın nedeni fiyat avantajlarından } \\
\text { faydalanmaktır. }\end{array}$ & & ,657 & & & & \\
\hline $\begin{array}{l}\text { Firsat sitelerinde satışa sunulan mal/hizmetlerin fiyatları makul } \\
\text { düzeydedir. }\end{array}$ & & 612 & & & & \\
\hline Fırsat sitelerinden yapılan alışveriş hesaplı değildir.* & &, 545 & & & & \\
\hline \multicolumn{7}{|l|}{ İtibar (Açıklanan varyans:\%12,556, Cronbach Alfa: ,869) } \\
\hline Firsat siteleri itibarlıdır. & & &, 841 & & & \\
\hline Firsat siteleri prestij sahibidir. & & & ,784 & & & \\
\hline Fırsat siteleri iyi bir üne sahiptir. & & &, 780 & & & \\
\hline Firsat siteleri saygındır. & & &, 707 & & & \\
\hline Fırsat siteleri sürekli olarak kaliteli mal/hizmet sunar. & & & 509 & & & \\
\hline \multicolumn{7}{|l|}{ Sosyal değer (Açılanan varyans: \%12,294, Cronbach Alfa: ,872) } \\
\hline $\begin{array}{l}\text { Fırsat sitelerinden alışveriş yapmak sosyal açıdan kabul görmeme } \\
\text { yardımcıdır. }\end{array}$ & & & &, 881 & & \\
\hline $\begin{array}{l}\text { Fırsat sitelerinden alışveriş yapmak çevremdekiler üzerinde iyi izlenim } \\
\text { bırakmama yardımcı olur. }\end{array}$ & & & &, 878 & & \\
\hline $\begin{array}{l}\text { Fırsat sitelerinden alışveriş yaptığımda çevrem tarafından kabul } \\
\text { gördüğümü hissederim. }\end{array}$ & & & &, 820 & & \\
\hline $\begin{array}{l}\text { Fırsat sitelerinden alışveriş yaptığımda çevremdekilerin bana bakışı } \\
\text { olumsuz olur. }\end{array}$ & & & &, 706 & & \\
\hline \multicolumn{7}{|l|}{ Davranışsal fiyat (Açılanan varyans:\%9,593, Cronbach Alfa: } \\
\hline \multicolumn{7}{|l|}{,831) } \\
\hline Fırsat sitelerinden alışveriş yapmak kolay değildir.* & & & & &, 810 & \\
\hline Fırsat sitelerinden alışveriş çok çaba gerektirir.* & & & & &, 808 & \\
\hline Fırsat sitelerinden alışveriș yapmak için az enerji harcanır. & & & & &, 753 & \\
\hline Fırsat sitelerinden kolayca satın alım yapılabilir. & & & & & 660 & \\
\hline \multicolumn{7}{|l|}{ Fonksiyonel değer (Açılanan varyans: \%6,765, Cronbach Alfa: } \\
\hline Firsat siteleri istikrarlı hizmet sunar. & & & & & &, 723 \\
\hline Fırsat sitelerinin kalite standardı kabul edilebilir ölçüdedir. & & & & & & 683 \\
\hline Fırsat siteleri iyi tasarlanmıştır. & & & & & & ,437 \\
\hline $\begin{array}{l}\text { Toplam açıklanan varyans: } \% 68,4 \\
\text { Cronbach Alfa: ,889 } \\
\text { Kaiser-Meyer-Olkin Örnekleme Uygunluk Ölçümü =,868; } \\
\text { Barlett küresellik testi }=5540,327, p=, 000(d f=378) * p<, 01\end{array}$ & & & & & & \\
\hline
\end{tabular}

*Olumsuz ifadeler analiz öncesi ters kodlanmıştır.

Varimax rotasyonu sonucu elde edilen altı faktör ve değişkenlere ait faktör yükleri Tablo 3'de görülmektedir. Faktörlerin toplam içerisinde açıkladıkları varyans oranları ile birlikte her bir faktör altında yer alan değişkenlerin Cronbach Alfa değerleri de tabloda yer almaktadır. Tablo 3'de görüldüğü üzere tüketim değerleri ölçeği 0,889 oranında güvenilir bulunmuştur. Cronbach Alfa değeri için genellikle kabul edilen alt limit 0,70’tir ancak keşfedici araştırmalarda bu değer 0,60'a kadar düșebilmektedir (Hair vd., 2010, s.125). Tablo 3'de görüldügüü üzere altı faktörün her birine ait Cronbach Alfa değeri 0,70'in üzerindedir. Buna göre ölçek içerisindeki değişkenlerin içsel tutarlılığ 1 yüksektir. Ayrıca, satın alma niyetini ölçen değişkenlere uygulanan güvenirlik analizi sonucu Cronbach Alfa değerinin 0,876 olduğu, firsat sitelerine duyulan bağlılığ 1 ölçmeye yönelik değişkenlerin ise 0,868 oranında güvenilir olduğu saptanmıştır. 
Farklı Tüketim Değeri Boyutlarının Satın Alma Niyeti Üzerindeki Etkisinin Belirlenmesi

Keşfedici faktör analizi sonrası elde edilen tüketim değeri boyutları arasından, firsat sitelerine duyulan bağlllık ve satın alma niyeti üzerinde etki eden faktörlerin ağırlıkları doğrusal regresyon analizi ile be- lirlenmeye çalışılmıştır. Tüketim değerlerinin fırsat sitelerinden satın alma niyeti üzerindeki etki düzeylerini belirlemek amacıyla gerçekleştirilen regresyon analizine yönelik sonuçlar aşağıda Tablo 4, Tablo 5 ve Tablo 6'da özet bir biçimde sunulmuştur.

Tablo 4. Satın Alma Niyeti ile Tüketim Değerleri Arasındaki ilişkiyi Ölçen Regresyon Analizinin Özeti

\begin{tabular}{|c|c|c|c|c|c|c|c|c|c|c|}
\hline \multirow[b]{2}{*}{ Model } & \multirow[b]{2}{*}{$\mathbf{R}$} & \multirow[b]{2}{*}{ R Kare } & \multirow[b]{2}{*}{$\begin{array}{c}\text { Düzeltilmiş } \\
\text { R Kare }\end{array}$} & \multirow[b]{2}{*}{$\begin{array}{l}\text { Std. } \\
\text { Hata }\end{array}$} & \multicolumn{5}{|c|}{ Değişim İstatistikleri } & \multirow[b]{2}{*}{$\begin{array}{l}\text { Durbin- } \\
\text { Watson }\end{array}$} \\
\hline & & & & & $\begin{array}{l}\text { R Kare } \\
\text { Değișimi }\end{array}$ & $\begin{array}{c}F \\
\text { Değeri }\end{array}$ & df1 & df2 & $\begin{array}{c}\text { Anlamlılık } \\
\text { Düzeyi }\end{array}$ & \\
\hline 1 & 667 & 445 & 435 & ,58089 & 445 & 41,368 & 6 & 309 &, 000 & 1,832 \\
\hline
\end{tabular}

Tablo 4'de görüldüğü üzere F değeri 41,368'in 0,000 anlamlılık düzeyinde olması modelin bir bütün olarak geçerli olduğunu göstermektedir. Analiz sonucu korelasyon katsayısı 0,667 olarak bulunmuştur. Buna göre bağımlı değişken olan satın alma niyetindeki değişimin \%43,5'inin modele dâhil edilen tüketim değerleri tarafından açıklanabildiği ve anlamlı olduğu görülmektedir. Ayrıca modelde otokorelasyon olup olmadığını gösteren ve genellikle 1,5 ile 2,5 arasında değerlerin otokorelasyon olmadığı sonucuna varabildiğimiz Durbin-Watson testi (Kalaycı, 2009, s.267) sonucu 1,832 çıkmıştır. Regresyon analizine giren değişkenler arasındaki korelasyon değerleri ise Tablo 5 'de gösterilmektedir. Bağımsız değişkenler arasında 0,80 ve üzerinde korelasyon var ise, bu durumun çoklu bağıntı probleminin göstergesi olduğu bilinmektedir (Kalayc1, 2009, s.267). Görüldüğü üzere faktörler arasında güçlü bir korelasyon bulunmamaktadır.

Tablo 5. Satın Alma Niyeti ve Tüketim Değerlerine Illişkin Boyutlar Arasındaki Korelasyon Matrisi

\begin{tabular}{lccccccc}
\hline & $\mathbf{1}$ & $\mathbf{2}$ & $\mathbf{3}$ & $\mathbf{4}$ & $\mathbf{5}$ & $\mathbf{6}$ & $\mathbf{7}$ \\
\hline Satın Alma Niyeti & 1,000 & & & & & & \\
Duygusal Değer &, 559 & 1,000 & & & & & \\
Parasal Fiyat &, 464 &, 394 & 1,000 & & & & \\
İtibar &, 521 &, 508 &, 447 & 1,000 & & & \\
Sosyal Değer &, 206 &, 111 &,- 053 &, 262 & 1,000 & & \\
Davranıssal Fiyat &, 298 &, 346 &, 410 &, 217 &,- 249 & 1,000 & \\
Fonsiyonel Değer &, 464 &, 533 &, 465 &, 622 &, 152 &, 249 & 1,000 \\
\hline
\end{tabular}

Tablo 6'da modelin tahmini sonucu elde edilmiş olan parametre değerleri ve her bir boyuta ait $t$ değerleri yer almaktadır. Tablo 6 'da görüldügü üzere, bağımsız değişkenlere ait katsayılardan $\left(\mathrm{x}_{1}=\right.$ Duygusal Değer, $x_{2}=$ Parasal Fiyat, $x_{3}=$ İtibar, $x_{4}=$ Sosyal Değer, $\mathrm{x}_{5}=$ Davranışsal Fiyat, $\mathrm{x}_{6}=$ Fonksiyonel Değer) Dav- ranışsal Fiyat ve Fonksiyonel Değer boyutlarına ait değerler dışında tüm $t$ değerleri anlamlıdır. Duygusal Değer boyutunun beta katsayısı en yüksek, sonrasında sirasiyla Parasal Fiyat, İtibar ve Sosyal Değer faktörlerine ait beta katsayıları izlemektedir.

Tablo 6. Satın Alma Niyeti ile Tüketim Değerleri Arasındaki Ilişkileri Ölçen Regresyon Modelinin Beta Katsayıları ve Anlamlılık Düzeyleri

\begin{tabular}{|c|c|c|c|c|c|}
\hline \multicolumn{6}{|l|}{ Model } \\
\hline & \multicolumn{2}{|c|}{ Standartlaștırılmamıș Katsayılar } & \multicolumn{3}{|c|}{ Standartlaștırılmıș Katsayılar } \\
\hline & B & Std. Hata & Beta & $\mathbf{t}$ & Anl. \\
\hline (Sabit) &,- 104 &, 256 & &,- 405 & ,686 \\
\hline Duygusal Değer & ,334 &, 057 & ,314 & 5,833 &, 000 \\
\hline Parasal Fiyat & ,257 &, 064 & ,211 & 4,018 &, 000 \\
\hline İtibar & 199 &, 064 & ,184 & 3,117 &, 002 \\
\hline Sosyal Değer &, 135 &, 042 & ,151 & 3,232 &, 001 \\
\hline Davranışsal Fiyat & ,097 &, 053 & 091 & 1,822 &, 069 \\
\hline Fonsiyonel Değer & ,042 &, 065 & ,038 &, 648 &, 518 \\
\hline
\end{tabular}


Davranışsal Fiyat ve Fonksiyonel Değer boyutları ise bağımlı değişkeni (satın alma niyeti) anlamlı olarak açıklamamaktadır. Ayrıca bağımlı değişkeni anlamlı olarak açıklayan katsayıların pozitif olması bağımsız değişkenlerle bağımlı değişken arasındaki ilişkinin pozitif yönlü olduğunu göstermektedir. Buna göre araştırma modelinin anlamlı olan katsayıları ile oluşturulan regresyon denklemi aşağıda yer almaktadır:

$$
\mathrm{y}=0,314 \mathrm{x}_{1}+0,211 \mathrm{x}_{2}+0,184 \mathrm{x}_{3}+0,151 \mathrm{x}_{4}
$$

Denklem standardize edilmiş regresyon katsayılarına göre oluşturulmuştur. Anlamlı bulunmadığı için $\mathrm{x}_{5}$ (Davranışsal Fiyat) ve $\mathrm{x}_{6}$ (Fonksiyonel Değer) boyutlarına ait katsayılara denklemde yer verilmemiştir.
Tablo 6'da görüldüğü üzere, en yüksek beta katsayıs1na sahip olan $\mathrm{x}_{1}$ (Duygusal Değer) boyutundaki bir birimlik artışın satın alma niyetini 0,334 arttırdığ görülmektedir. En düşük beta katsayısına sahip olan $\mathrm{x}_{4}$ (Sosyal Değer) boyutundaki bir birimlik artış ise tüketicilerin satın alma niyetini 0,135 arttırmaktadır.

\section{Farklı Tüketim Değeri Boyutlarının Fırsat Sitelerine Duyulan Bağlılık Üzerindeki Etkisinin Belirlenmesi}

Tüketim değerlerinin tüketicilerin firsat sitelerine duydukları bağlılık üzerindeki etki düzeylerini belirlemek amacıyla gerçekleştirilen regresyon analizine yönelik sonuçlar aşağıda Tablo 7, Tablo 8 ve Tablo 9'da özet bir biçimde sunulmuştur.

Tablo 7. Fırsat Sitelerine Duyulan Bağlıık ile Tüketim Değerleri Arasındaki İlişkiyi Ölçen Regresyon Analizinin Özeti

\begin{tabular}{|c|c|c|c|c|c|c|c|c|c|c|}
\hline \multirow[b]{2}{*}{ Model } & \multirow[b]{2}{*}{$\mathbf{R}$} & \multirow[b]{2}{*}{ R Kare } & \multirow[b]{2}{*}{$\begin{array}{c}\text { Düzeltilmiş } \\
\text { R Kare }\end{array}$} & \multirow[b]{2}{*}{ Std. Hata } & \multicolumn{5}{|c|}{ Değișim İstatistikleri } & \multirow[b]{2}{*}{$\begin{array}{l}\text { Durbin- } \\
\text { Watson }\end{array}$} \\
\hline & & & & & $\begin{array}{l}\text { R Kare } \\
\text { Değişimi }\end{array}$ & $\begin{array}{c}F \\
\text { Değeri }\end{array}$ & df1 & df2 & $\begin{array}{c}\text { Anlamlılık } \\
\text { Düzeyi }\end{array}$ & \\
\hline 1 & 661 & ,437 & ,426 & ,59422 & ,437 & 39,912 & 6 & 309 & 000 & 1,738 \\
\hline
\end{tabular}

Tablo 7’de görüldüğü üzere, modelin bir bütün olarak geçerliliği, F değerinin 39,912 olması ile 0,000 anlamlılık düzeyinde sağlanmıştır. Analiz sonucu korelasyon katsayısı 0,661 olarak tespit edilmiştir. Tüketim değerlerinin fırsat sitelerine yönelik tüketicilerin bağlılığının \%42,6’sını açıkladığı ve modelin anlamlı olduğu görülmektedir. Ayrıca modelde otokorelasyon olup olmadığını gösteren ve genellikle 1,5 ile 2,5 arasinda değerlerin otokorelasyon olmadiğı sonucuna varabildiğimiz Durbin-Watson testi (Kalayc1, 2009, s.267) sonucu 1,738 çıkmıştır. Regresyon analizine giren değişkenler arasındaki korelasyon değerleri Tablo 8'de gösterilmektedir. Görüldüğü üzere faktörler arasında güçlü bir korelasyon bulunmamaktadır.

Tablo 8. Bağlılık ve Tüketim Değerlerine Illişkin Boyutlar Arasındaki Korelasyon Matrisi

\begin{tabular}{lccccccc}
\hline & $\mathbf{1}$ & $\mathbf{2}$ & $\mathbf{3}$ & $\mathbf{4}$ & $\mathbf{5}$ & $\mathbf{6}$ & $\mathbf{7}$ \\
\hline Bağlılık & 1,000 & & & & & & \\
Duygusal Değer &, 507 & 1,000 & & & & \\
Parasal Fiyat &, 452 &, 394 & 1,000 & & & \\
İtibar &, 563 &, 508 &, 447 & 1,000 & & \\
Sosyal Değer &, 253 &, 111 &,- 053 &, 262 & 1,000 & \\
Davranışsal Fiyat &, 226 &, 346 &, 410 &, 217 &,- 249 & 1,000 &, 249 \\
Fonsiyonel Değer &, 440 &, 533 &, 465 &, 622 &, 152 & 1,000 \\
\hline
\end{tabular}

Tablo 9'da modelin tahmini sonucu elde edilmiş olan parametre değerleri ve her bir boyuta ait $t$ değerleri yer almaktadır. Tablo 9'da görüldügü üzere, bağımsız değişkenlere ait katsayılardan $\left(\mathrm{x}_{1}=\right.$ Duygusal Değer, $\mathrm{x}_{2}=$ Parasal Fiyat, $\mathrm{x}_{3}=$ İtibar, $\mathrm{x}_{4}=$ Sosyal Değer, $\mathrm{x}_{5}=$ Davranışsal Fiyat, $\mathrm{x}_{6}=$ Fonksiyonel Değer) Davranışsal Fiyat ve Fonksiyonel Değer boyutlarına ait değerler dışında tüm $\mathrm{t}$ değerleri anlamlıdır. Beta katsayısı en yüksek İtibar boyutunun çıkarken, onu
Duygusal Değer ve Parasal Fiyat boyutu takip etmektedir. Sosyal Değer boyutu en düşük beta katsayısına sahiptir. Davranışsal Fiyat ve Fonksiyonel Değer boyutları ise bağımlı değişkeni (bağlılık) anlamlı olarak açıklamamaktadır. Bununla birlikte, bağımlı değişkeni anlamlı olarak açıklayan katsayıların pozitif olması bağımsız değişkenlerle bağımlı değişken arasındaki ilişkinin pozitif yönlü olduğunu göstermektedir. 
Tablo 9. Fırsat Sitelerine Duyulan Bağlıık ile Tüketim Değerleri Arasındaki Illişkileri Ölçen Regresyon Modelinin Beta Katsayıları ve Anlamlılık Düzeyleri

\begin{tabular}{|c|c|c|c|c|c|}
\hline \multicolumn{6}{|l|}{ Model } \\
\hline & \multicolumn{2}{|c|}{ Standartlaştırılmamış Katsayılar } & \multicolumn{3}{|c|}{ Standartlaştırılmış Katsayılar } \\
\hline & B & Std. Hata & Beta & $\mathbf{t}$ & Anl. \\
\hline (Sabit) &,- 226 & ,262 & &,- 863 & ,389 \\
\hline Duygusal Değer & ,266 &, 059 & ,246 & 4,537 &, 000 \\
\hline Parasal Fiyat &, 280 &, 065 & ,227 & 4,277 &, 000 \\
\hline İtibar & ,322 &, 065 & ,293 & 4,933 &, 000 \\
\hline Sosyal Değer &, 155 &, 043 &, 171 & 3,619 &, 000 \\
\hline Davranışsal Fiyat &, 032 &, 054 &, 029 &, 587 & ,558 \\
\hline Fonsiyonel Değer &,- 015 &, 066 &,- 013 &,- 221 &, 825 \\
\hline
\end{tabular}

Buna göre araştırma modelinin anlamlı olan katsayıları ile oluşturulan regresyon denklemi aşağıda yer almaktadir:

$$
y=-0,246 x_{1}+0,227 x_{2}+0,293 x_{3}+0,171 x_{4}
$$

Denklem standardize edilmiş regresyon katsayılarına göre oluşturulmuştur. Anlamlı bulunmadığı için $\mathrm{x}_{5}$ (Davranışsal Fiyat) ve $\mathrm{x}_{6}$ (Fonksiyonel Değer) boyutlarına ait katsayılara denklemde yer verilmemiştir. Tablo 9'da görüldüğü üzere, en yüksek beta katsay1sina sahip olan $\mathrm{x}_{3}$ (İtibar) boyutundaki bir birimlik artışın bağlılığ 0,322 arttırdığ 1 görülmektedir. En düşük beta katsayısına sahip olan $\mathrm{x}_{4}$ (Sosyal Değer) boyutundaki bir birimlik artış ise tüketicilerin fırsat sitelerine yönelik bağlılığ 0,155 arttırmaktadır.

\section{Araştırmanın Kısıtları, Sonuç ve Değerlendirmeler}

Çalışma kapsamında tüketicilerin, günlük fırsat sitelerinden yapılan alışverişe yönelik atfettikleri değerin bu sitelerden satın alma niyetleri ve bağlilıkları üzerindeki etkisinin incelenmesi konu alınmıştır. Bu çalışma ile pazarlama literatürüne, yeni ve sürekli gelişen bir iş modeli olan firsat sitelerine yönelik tüketici değer algılamalarının araştırılması ile katkı sağlayacağ1 düşünülmektedir. Araştırmada, tüketicilerin tüketim değerleri ve çeşitli tüketici özelliklerini ölçmede kullanılan ölçeklerin öncelikli olarak dilimize doğru ve anlaşılır şekilde uyarlanmasına çalışılmıştır. İfadelerin anlaşılırlığı ve Türk tüketicisine uygun hale getirilmesinin dikkat edilmesi gereken bir konu olması nedeniyle, ilgili ölçeklerin kullanıldığı yerel düzeyde çalışmalar incelenmiş; ifadeler nihai anket uygulaması öncesinde literatürdeki uygulamalar, farklı tüketici grupları ve konu ile ilgili araştırmacıların görüşleri doğrultusunda düzenlenmiştir. Bunun yanı sıra fırsat siteleri ve özel alışveriş kulüpleri gibi kavramların ülkemizde ve dünya genelinde de oldukça yeni bir sektör kolu olduğu göz önünde bulundurulduğunda, kavramın cevaplayıcılar tarafından anlaşılırlığı ve aşinalığ 1 dikkat edilen başka bir noktadır.

Araştırmada tüketim değerlerinin, firsat sitelerine duyulan bağlllık ve satın alma niyeti üzerindeki etkisi doğrusal regresyon analizi ile belirlenmiştir. Öncelikli olarak tüketim değerlerini ölçen değişkenlere keşfedici faktör analizi uygulanmış ve toplam altı faktör $\left(\mathrm{x}_{1}=\right.$ Duygusal Değer, $\mathrm{x}_{2}=$ Parasal Fiyat, $\mathrm{x}_{3}=$ İtibar, $\mathrm{x}_{4}=$ Sosyal Değer, $\mathrm{x}_{5}=$ Davranışsal Fiyat, $\mathrm{x}_{6}=$ Fonksiyonel Değer) elde edilmiş̧ir. Gerçekleştirilen regresyon analizleri ile tüketim değerleri içerisinde hangi boyutların davranışlar üzerinde daha çok etkili olduğunun açılklanması hedeflenmiştir. Bağımlı değişken (y) olarak hem satın alma niyeti hem de firsat sitelerine duyulan bağlılığı ölçmeye yönelik beşli likert tipi ölçekle sunulan ifadelere çalışmada yer verilmiştir. Bu doğrultuda bağımsız değişkenlerin bağımlı değişkenler üzerindeki etkileri incelenmeye çalışılmış, $\mathrm{y}=\mathrm{a}+\mathrm{b} 1 \mathrm{x}_{1}+\mathrm{b} 2 \mathrm{x}_{2}+\mathrm{b} 3 \mathrm{x}_{3}+\mathrm{b} 4 \mathrm{x}_{4}+\mathrm{b} 5 \mathrm{x}_{5}+\mathrm{b} 6 \mathrm{x}_{6}$ eşitliği doğrultusunda araştırma hipotezleri test edilmiştir. Anlamlı çıkan regresyon modeli, tüketim değerlerinin tüketicilerin satın alma niyetinin \%44,5'ini, bağlılığın \%43,7'ini açıklamaktadır. Araştırma amacı doğrultusunda, satın alma niyeti için oluşturulan $\mathrm{H}_{1}$ hipotezi (Tüketim değerleri ile tüketicilerin fırsat sitelerinden satın alma niyeti arasında pozitif bir ilişki vardır) parçalı kabul edilmiştir. Satın alma niyetine en fazla Duygusal Değer boyutu, sonrasında sırasıyla Parasal Fiyat, İtibar ve Sosyal Değer faktörleri etki etmektedir. $\mathrm{Bu}$ doğrultuda oluşturulan $\mathrm{H}_{1 \mathrm{~b}}, \mathrm{H}_{1 \mathrm{c}}, \mathrm{H}_{1 \mathrm{~d}}$ ve $\mathrm{H}_{1 \mathrm{f}}$ hipotezleri kabul edilmiştir. Bununla birlikte Davranışsal Fiyat ve Fonksiyonel Değer boyutları ise satın alma niyeti değişkenini anlamlı olarak açıklamamaktadır. Bu doğrultuda alt hipotezlerden $\mathrm{H}_{1 \mathrm{a}}, \mathrm{H}_{1 \mathrm{e}}$ hipotezleri reddedilmiştir. Fırsat sitlerine duyulan bağllilk üzerine araştırma amacı doğrultusunda oluşturulan 
$\mathrm{H}_{2}$ hipotezi (Tüketim değerleri ile tüketicilerin firsat sitelerine duydukları bağlılık arasında pozitif yönlü bir ilișki vardır) ise parçalı kabul edilmiștir. Satın alma niyetine en fazla İtibar boyutu, sonrasında sırasiyla Parasal Fiyat, Duygusal Değer ve Sosyal Değer faktörleri etki etmektedir. Bu doğrultuda oluşturulan $\mathrm{H}_{2 \mathrm{~b}}, \mathrm{H}_{2 \mathrm{c}}, \mathrm{H}_{2 \mathrm{~d}}$ ve $\mathrm{H}_{2 \mathrm{f}}$ hipotezleri kabul edilmiştir. Bununla birlikte Davranışsal Fiyat ve Fonksiyonel Değer boyutları ise bağlılık değişkenini anlamlı olarak açıklamamaktadır. $\mathrm{Bu}$ doğrultuda alt hipotezlerden $\mathrm{H}_{2 \mathrm{a}}$, $\mathrm{H}_{2 \mathrm{e}}$ hipotezleri reddedilmiştir.

Araştırma sonuçları doğrultusunda, tüketicilerin duygusal değer algılamalarının, satın alma niyetini üzerinde en fazla rolü olduğunu söylenebilir. Tüketicilerin tekrar satın alım yapmalarına ve söz konusu sitelerin daimi kullanıcıları olmalarına yönelik değișkenleri kapsayan firsat sitelerine duyulan bağlllık değişkeni üzerinde ise İtibar boyutu en fazla etkiye sahiptir. Buna göre İnternet perakendeciliğinin yeni ve sürekli gelişen bir iş kolu olan günlük fırsat sitelerinin, kullanıcıları siteyi takip etmeye ve satın alım yapmaya çeken yönleri üzerine yoğunlaşmaları olasıdır.

$\mathrm{Bu}$ verilerden hareketle, açılanan varyans itibariyle tüketicilerin firsat sitelerinden satın alma niyeti ve bu sitelere bağlllığı üzerinde, değer algılamalarına ilişkin boyutlar haricinde başka faktörlerin de (alg1lanan risk ve fayda, marka sadakati, tüketicilerin alışveriş alışkanlıkları, firmaların pazarlama faaliyetleri vb.) etkisi olabileceği öngörülmüştür. İleriye dönük olarak yapılacak çalışmalarda, fırsat sitelerinden yapılan alışverişe atfedilen değerin, sunulan ürünler ya da markalar bazında farklılaşıp farklılaşmadığı; tüketim değeri, satın alma niyeti ve/veya bağlılık üzerinde tüketiciye özgü karakteristiklerin (plansız ya da aşırı tüketim eğilimi, tüketicinin seçenek arayışı, fiyat hassasiyeti, marka bilinci vb.) etkili olup olmadığ 1 araştırabilir. Bunun yanı sıra, satın alma alışkanlıkları ve İnternet kullanım alıșkanlıklarına dair tüketiciler arası karşılaştırmalar ya da risk algısı ve İnternetten alışverișe duyulan güven unsuru gibi hususlar da gelecekteki araştırmalar için göz önünde bulundurulabilir. Ayrıca firsat sitelerinden satın alma niyeti ve bağlllık üzerinde etkili olabilecek sosyo-demografik, psikolojik ya da kültürel etkenler de ileriye dönük olarak araştırılabilecek konular arasındadır.
Uygulama açısından bakıldığında ise, araştırma sonuçları doğrultusunda tüketicileri satın almaya iten faktörlerin başında, tüketicilerin bu alışverișten aldıkları keyif unsurunun geldiği görülmektedir. Fiyat algısı, sitelerin itibarı ve kişinin sosyal değer algısı ise daha sonra gelmektedir. Tüketicilerin alışverişten zevk almalarının, firsat sitelerini takip etmeyi ve buradan alışveriş yapmayı seçmesi üzerinde diğer parasal, sosyal ya da özellikle fonksiyonel unsurlara kıyasla daha fazla etkili olduğu saptanmıştır. Bu sebeple bu iş kolunda faaliyet göstermek isteyen veya göstermekte olan girişimcilerin İnternet sitelerini ve kampanyalar ile ürünleri tüketicinin zevkine hitap eden şekilde sunmaları ve tasarlamaları önerilebilir. Tüketinin alışveriş yaparken kendini rahat hissetmesini sağlayacak, alışverişi bir duygusal deneyime dönüştürecek bir İnternet mağazası atmosferi ile oluşturulabilecek site düzeni, tüketiciyi satın alma kararına yönelten en önemli unsurdur. Bunun haricinde firsat sitelerinin işletme modelindeki bir diğer önemli öğe olan indirimli satış, parasal olarak tüketicinin yaptığı alışverişten duyduğu memnuniyeti ve hesaplı bir alışveriş yaptığına dair algısını güçlendirmektedir. Örneğin, firmaların, yapılan kampanyalar ve indirimlere dair sunuş biçimlerini ve yollarını, tüketiciye duygusal ve rasyonel açıdan daha yakın gelecek şekilde tasarlamaları tüketicinin nihai satın alma kararında onları diğerlerinden üstün kılabilir. Çünkü çalışmada tespit edildiği üzere, tüketici, satın alma kararını verirken sadece sosyal bağlantılarını ya da sadece fonksiyonel açıdan kullanışlı bir İnternet sitesi olup olmadığını göz önünde bulundurmamaktadır.

Tüketicilerin fırsat sitelerinden alı̧veriş yapmaya devam etmesinde, yani o siteye bağlı kalmasında ise bu sitelerin itibarlı ve kalite açısından istikrarlı olmaları en fazla role sahiptir. Duygusal değer, fiyat algisı ve kişinin sosyal değer algısı ise sonrasında gelmektedir. Tüketicilerin satın alımlarını sürdürmesi ve siteler hakkında olumlu deneyimlerini paylaşması açısından, bu iş kolunda faaliyet gösteren işletmelerin sitelerin iyi şekilde tanınması ve kaliteli hizmet sunmasına özellikle önem göstermesi gerekmektedir. Bunun yanı sıra firmaların, site tasarımında tüketicilere sunulacak duygusal deneyimler ile tutundurma amaçlı stratejilerinde fiyat unsuruna ve sosyal bağlantıları daha aktif şekilde kullanmaya özen göstermeleri gerektiği araştırma sonuçları doğrultusunda söylenebilir. 


\section{Kaynakça}

Afra, S. (2011). Av Mevsimi: Grup Satın Alma, http://www.sinaafra.com/av-mevsimi-grupsatinalma-2011 (Erişim Tarihi: 14.11.2011).

Ar, A. A. (2012). Effect Of Perceived Values on The Brand Preference and The Purchase Intention. European Scientific Journal, 8(17), ISSN: 1857 - 7881.

Babin, B. J., Darben, W. R. ve Griffin, M. (1994). Work and/or Fun: Measuring Hedonic and Utilitarian Shopping Value. Journal of Consumer Research, 20(1): 644-656.

Bødker, M., Gimpel, G. ve Hedman, J. (2009). The User Experience of Smart Phones: A Consumption Values Approach. In: Eighth Global Mobility Roundtable, Cairo, Egypt.

Boksberger P. E. ve Melsen L. (2011). Perceived Value: A Critical Examination of Definitions, Concepts and Measures for the Service Industry. Journal of Services Marketing, 25(3): 229-240.

Boon, E., Wiid, R. ve DesAutels, P. (2012). Teeth Whitening, Boot Camp, and A Brewery Tour: A Practical Analysis of 'Deal of the Day'. Journal of Public Affairs, 12(2): 137-144.

Chang, H.H; Wang, Y.H ve Yang W.Y. (2009). The Impact of E-Service Quality, Customer Satisfaction and Loyalty on E-Marketing: Moderating Effect of Perceived Value. Total Quality Management \& Business Excellence, 20(4): 423-443.

Chen, Z. ve Dubinsky, A. J. (2003). A Conceptual Model of Perceived Customer Value in E-Commerce: A Preliminary Investigation. Psychology and Marketing, 20(4): 323-347.

Cheng J. M.S., Wang E. S.T., Lin J. Y.C. ve Vivek S. D. (2009). Why Do Customers Utilize the Internet As a Retailing Platform?: A View from Consumer Perceived Value. Asia Pacific Journal of Marketing and Logistics, 21(1): 144-160.

Chi, H.K., Yeh, H.R. ve Jang, B.F. (2008). The Effects of Service Quality, Customer Perceived Value, Customer Satisfaction on Behavioral Intentions: A Study of Mobile Value-Added Services in Taiwan. The Business Review, 10(1): 129-135.
Devaraj, S. Fan, M. ve Kohli, R. (2002). Antecedents of B2C Channel Satisfaction and Preference: Validating e-Commerce Metrics. Information Systems Research, 13(3): 316-333.

Dodds, W. B., Monroe, K. B. ve Grewal, D. (1991). The Effects of Price, Brand, and Store İnformation on Buyers' Product Evaluations. Journal of Marketing Research, 28(3): 307-319.

Dragt, B. (2012). A Seamless, Personalized Purchase Experience for Today's Connected Consumers. A First Data White Paper Universal Commerce, First Data Corporation, http://www.firstdata.com/ downloads/thought-leadership/UnivComm-WP. pdf (Erişim Tarihi: 15.03.2013).

Ekonomist. E-ticarette Yeni Trend Tek Ürüne Odaklanmak. (2011, 27 Mart), http://www.ekonomist. com. tr/eticarette-yeni-trend-tek-urune-odaklanmakhaberler/2491.aspx (Erişim Tarihi: 15.05.2012).

Flavián, C. ve Guinalíu, M. (2007). Development and Validation of Familiarity, Reputation and Loyalty Scales for Internet Relationships. ESIC MARKET, January - April, 2007: 157-188.

Gupta, V. (2012). Profitability of Daily Discounts: Examining the Entry of Group Buying Websites into India and Benefits to Merchants. (2012, April 9), Working Paper Series, http://ssrn.com/ abstract=2102465 (Erişim Tarihi: 15.03.2013).

Hair, J. F., Black W. C., Babin B. J. ve Anderson R. E. (2010). Multivariate data analysis, A global perspective. 7. Basım, Pearson, Upper Saddle River, NJ.

Hughes, S. ve Beukes, C. (2012). Growth and Implications of Social E-Commerce and Group Buying Daily Deal Sites: The Case of Groupon and Livingsocial. International Business \& Economics Research Journal, 11(8): 921-934.

Johnson M. D., Herrmann A. ve Huber F. (2006). The Evolution of Loyalty Intentions. Journal of Marketing, 70(2): 122-132.

Kalaycı, Ş. (2009). SPSS Uygulamalı Çok Değişkenli İstatistik Teknikleri. Ankara: Asil Yayınevi. 
Kashyap, R. ve Bojanic, D. C. (2000). A Structural Analysis of Value, Quality, and Price Perceptions of Business and Leisure Travelers. Journal of Travel Research, 39 (1): 45-51.

Kim, H.W., Chan, H.C. ve Gupta S. (2007). Value-Based Adoption of Mobile Internet: An Empirical Investigation. Decision Support Systems, 43(1): 111126.

Kim, H., Koh, J. ve Lee, H. (2009). Investgating The Intention of Purchasing Digital Items in Virtual Communities. Pacific Asia Conference on Information Systems, (PACIS) 2009 Proceedings Association for Information System, Paper 18, http://aisel.aisnet.org/pacis2009/18.

Kim, H.W., Gupta, S. ve Koh, J. (2011). Investigating the Intention to Purchase Digital Items in Social Networking Communities: A Customer Value Perspective. Information \& Managemen, 48(6), 2011: 228-234.

Kleijnen, M., de Ruyter, K. ve Wetzels, M. (2007). An Assessment of Value Creation in Mobile Service Delivery and the Moderating Role of Time Consciousness. Journal of Retailing, 83(1): 33-46.

Kurtuluş, K., (2010). Araştırma Yöntemleri. İstanbul: Türkmen Kitapevi.

Lapierre, J. (2000). Customer-Perceived Value in Industrial Context. Journal of Business and Industrial Marketing, 15(2-3): 122-140.

Lee, J., Graefe, A. R. ve Burns, R. C. (2004). Service Quality, Satisfaction, and Behavioral Intention Among Forest Visitors. Journal of Travel \& Tourism Marketing, 17(1): 73-82.

Long, M. M. ve Schiffman, L. G. (2000). Consumption Values and Relationships: Segmenting the Market for Frequency Programs. The Journal of Customer Marketing, 17(3): 214-232.

Luarn, P. ve Lin, H.H. (2003). A Customer Loyalty Model for E-Service Context. Journal of Electronic Commerce Research, 4(4): 156-167.

Malhotra, N. K. (2010). Marketing Research, An Applied Orientation. 6.Basım, Pearson Education Inc.
Manzur, E., Sergio, O., Pedro, H., Fablo F. ve Radrigo, U. (2011). Store Brand and National Brand Promotion Attitudes Antecedents. Journal of Business Research, 64(3): 286-291.

Pelenk, A., Velioğlu, Ö. ve Değirmencioğlu, G. (2011). Tüketimin Yeni Odağı: Private Shopping Üzerine Bir İnceleme. Academic Journal of Information Technology, ISSN: 1309-1581, 2(4).

Petrick, J. F. (2002). Development of a Multi-Dimensional Scale for Measuring the Perceived Value of a Service. Journal of Leisure Research, 34(2): 119-134.

Petrick, J. F. (2004). The Roles of Quality, Value, and Satisfaction in Predicting Cruise Passengers' Behavioral Intentions. Journal Of Travel Research, 42(4): 392-407.

Pihlström, M. (2008). Perceived Value of Mobile Service Use and Its Consequences. Doctoral Dissertation, No. 176, HANKEN - Swedish School of Economics and Business Administration.

Pope, N. (1998). Consumption Values, Sponsorship Awareness, Brand and Product Use. Journal of Product and Brand Management, 7(2): 124-136.

Raghubir, P. (1998). Coupon Value: A Signal for Price?. Journal of Marketing Research, 35(3): 316-324.

Sarıyer, N. (2008). Gloval Ölçeği ile Belediye Hizmetlerinde Müşterinin Algıladığı Değerinin Belirlenmesi - Kayseri Büyükşehir Örneği. Gazi Üniversitesi İktisadi ve İdari Bilimler Fakültesi Dergisi, 10(3): 163-185.

Sheth, J. N., Newman, B. I. ve Gross, B. L. (1991a). Why We Buy What We Buy: A Theory of Consumption Values. Journal of Business Research, 22: 159-170.

Sheth, J. N., Newman, B. I. ve Gross, B. L. (1991b). Consumption Values And Market Choices: Theory and Applications. Cincinnati, $\mathrm{OH}$ : South-Western Publishing.

Sirdeshmukh, D., Singh, J. ve Sabol, B. (2002). Consumer Trust, Value, and Loyalty in Relational Exchanges. Journal of Marketing, 66(1): 15-37. 
Smith, J. B. ve Colgate, M. (2007). Customer Value Creation: A Practical Framework. Journal of Marketing Theory and Practice, 15(1): 7-23.

Srinivasan, S. S, Anderson, R. ve Ponnavolu, K. (2002). Customer Loyalty in E-Commerce: An Exploration of Its Antecedents and Consequences. Journal of Retailing, 78(1): 41-50.

Srisutto, S. (2010). Country Branding, Consumption Values, and Purchase Decision Confidence: A Case Study of Tourists to Thailand. Doctoral Dissertation. Lincoln University.

Sweeney, J. C. ve Soutar, G. N. (2001). Consumer Perceived Value: The Development of a Multiple Item Scale. Journal of Retailing, 77(2): 203-220.

Turan, A. H. ve Çolakoğlu, B. E. (2009). Yaşılı Tüketicilerde Algilanan Marka Değeri ve Satınalma Niyeti. Afyon Kocatepe Üniversitesi İ.̇.B.F. Dergisi, 11(1): 277-296.

Tuten, T. L. ve Ashley C. (2011). Promotional Strategies for Small Businesses: Group Buying Deals. Small Business Institute Journal, 7(2): 15-29.

Wang, Y. G., Lo, H. P., Chi, R. Y. ve Yang, Y. H. (2004). An Integrated Framework for Customer Value and Customer Relationship Management Performance: A Customer-Based Perspective from China. Managing Service Quality, 14(2/3): 169-182.
Woodruff, R. B. (1997). Customer Value: The Next Source for Competitive Advantage. Journal of the Academy of Marketing Science, 25(2): 139-153.

Wu, K. (2011). Customer Loyalty Explained by Electronic Recovery Service Quality: Implications of the Customer Relationship Re-Establishment for Consumer Electronics E-Tailers. Contemporary Management Research, 7(1): 21-44.

Xiao, G. ve Kim, J. O. (2009). The Investigation of Chinese Consumer Values, Consumption Values, Life Satisfaction, and Consumption Behaviors. Psychology \& Marketing, 26(7): 610-624.

Zeithaml, V. A. (1988). Consumer Perceptions of Price, Quality and Value: A Means-End Model and Synthesis of Evidence. Journal of Marketing, 52(3): 2-22.

Zeithaml, V. A. ve Bitner, M. J. (2000). Services Marketing: Integrating Customer Focus Across The Firm. Singapore: McGraw-Hill. 